бенка, которые болеют бронхиальной астмой, определено, что у больных с атопической астмой наличие медленного ацетиляторного статуса повышало шансы регистрации высоких показателей лабильности бронхов (ПЛБ больше $30 \%)$ в 4,4 раза по сравнению с быстрыми «ацетиляторами». Для атопического фенотипа болезни установлено наличие достоверных корреляционных связей показателей лабильности бронхов с тяжестью обструкции бронхов $(\mathrm{r}=0,7, \mathrm{p}<0,005)$, длительностью течения болезни $(\mathrm{r}=0,8, \mathrm{p}<0,001)$, частотой повторных госпитализаций больных $(\mathrm{r}=0,6, \mathrm{p}<0,05)$. У больных с неатопической формой болезни в зависимости от ацетиляторного статуса не зарегистрировано связей между показателями лабильности бронхов и клиническими особенностями течения заболевания.

Ключевые слова: астма, фенотип, дети, лабильность бронхов, ацетиляторный статус.

\title{
INDICES OF BRONCHIAL LABILITY IN CHILDREN WITH ATOPIC AND NONATOPIC BRONCHIAL ASTHMA DEPENDING ON ACETYLATION STATUS
}

\section{L.O. Bezrukov, S.I. Tarnavska, M.N. Garas, O.O. Shakhova}

Abstract. After comprehensive clinical, laboratory and instrumental investigations of 51 children, who suffer from bronchial asthma, it was determined that in patients with atopic asthma slow acetylation status increased the possibility to detect a severe bronchial lability (bronchial lability index more than $30 \%$ ) by 4,4 times compared to the patients with fast acetylation status. For atopic phenotype of disease availability of correlations between bronchial lability indices and bronchial obstruction severity was established $(r=0,7, p<0,005)$ as well as duration of illness $(r=0,8, p<0,001)$, frequency of rehospitalization of patients $(r=0,6, p<0,05)$. In patients with nonatopic form of the disease relationships between bronchial lability indices and clinical features of disease depending on acetylation status haven't been reported.

Key words: asthma, phenotype, children, bronchial lability, acetylation status.

Bukovinian State Medical University (Chernivtsi)

Рецензент - проф. Т.В. Сорокман
Buk. Med. Herald. - 2014. - Vol. 18, № 1 (69). - P. 12-15

Надійшла до редакції 18.11.2013 року

(C) Л.О. Безруков, С.І. Тарнавська, М.Н. Гарас, О.О. Шахова, 2014

УДК 616.699(575.2)(04)

\section{К.А. Владиченко, Л.Т. Савчук}

\section{АНАЛІЗ РЕЗУЛЬТАТІВ СПЕРМОГРАМ МЕДИЧНОГО ЦЕНТРУ ЛІКУВАННЯ БЕЗПЛІДЯ}

Буковинський державний медичний університет, м. Чернівці Медичний центр лікування безпліддя, м. Чернівці ${ }^{1}$

Резюме. Досліджено показники спермограм за 2010-2012 рр., які виконано в медичному центрі лікування безпліддя м. Чернівці. Оцінка спермограм проведена згідно з рекомендаціями ВООЗ 2000 р. Проведено статистичний аналіз результатів обстеження 1935 чоловіків,

Вступ. Близько 15 \% подружніх пар у всьому світі мають проблеми з природним настанням вагітності [1-5]. Згідно з даними ВООЗ, загальна частка фактору чоловічого безпліддя сягає 46 \% [2]. Порушення фертильності призводить до зростання безплідних шлюбів, малодітних сімей, розлучень і погіршення демографічних показників [1-5]. У порівнянні 3 досягнутими успіхами в лікуванні жіночого безпліддя терапія чоловічого безпліддя залишається малоефективною [5]. В останні роки відмічається стійка тенденція до збільшення кількості безплідних чоловіків $[1,3]$. Тому дослідження етіології, патогенезу, діагностики та лікування чоловічого безпліддя вважається пріоритетним напрямком сучасної андрології та репродуктології.

Мета дослідження. Провести аналіз показників спермограм у чоловіків, які звернулися для обстеження в центр лікування безпліддя. при якому з'ясовано загальну тенденцію до збільшення відсотка астенозооспермії за рахунок категорії В.

Ключові слова: чоловіче безпліддя, діагностика, спермограма.

Матеріал і методи. Проаналізовано результати обстеження 1935 чоловіків, яким проведено дослідження спермограми, згідно з рекомендаціями ВОО3 2000 р., за допомогою інвертованого мікроскопа Olympus CKX41 у chamber Makler. Окрему групу склали 188 чоловіків, у яких верифіковано азооспермію.

Результати дослідження та їх обговорення. Аналіз результатів дослідження виявив, що існує загальна тенденція до значного зниження рухомих сперматозоїдів категорії В (табл. 1).

У пацієнтів із азооспермією в досліджуваних показниках, а саме - час розрідження, об'єм, в'язкість, не виявлено вірогідно значимих відхилень (табл. 2). Встановлено тенденцію до менших показників об' єму еякуляту в пацієнтів із азооспермією.

Регресійний аналіз між віком та об'ємом еякуляту в пацієнтів досліджуваної групи у 
Таблиця 1

Аналіз даних спермограм паціснтів за 2010-2012 pp. (x \pm Sx)

\begin{tabular}{|c|c|c|c|}
\hline Показники & 3a 2010 p., $\mathrm{n}=534$ & 3a 2011 p., $\mathrm{n}=722$ & 3a 2012 p., $\mathrm{n}=679$ \\
\hline Вік, роки & $31,84 \pm 11,80$ & $31,70 \pm 6,62$ & $31,69 \pm 6,20$ \\
\hline Час розрідження, хв & $29,16 \pm 12,17$ & $25,69 \pm 9,11$ & $25,62 \pm 9,77$ \\
\hline В’язкість, см & $0,16 \pm 0,14$ & $0,16 \pm 0,81$ & $0,13 \pm 0,10$ \\
\hline Об'єм, мл & $3,33 \pm 1,26$ & $3,38 \pm 1,59$ & $3,37 \pm 1,54$ \\
\hline $\begin{array}{c}\text { Кількість сперматозоїдів } \\
\text { в 1 мл еякуляту, млн }\end{array}$ & $36,63 \pm 29,17$ & $44,99 \pm 33,28$ & $42,81 \pm 29,38$ \\
\hline Кількість сперматозоїдів в еякуляті, млн & $123,74 \pm 121,18$ & $145,54 \pm 122,69$ & $136,74 \pm 105,67$ \\
\hline $\begin{array}{c}\text { Категорія А (рух швидкий, } \\
\text { прямолінійний), \% }\end{array}$ & $29,62 \pm 14,86$ & $33,69 \pm 15,63$ & $30,69 \pm 15,12$ \\
\hline $\begin{array}{c}\text { Категорія В (рух повільний } \\
\text { прямолінійний), \% }\end{array}$ & $15,40 \pm 9,28$ & $12,81 \pm 8,64$ & $13,13 \pm 7,92$ \\
\hline Категорія С (рух непрямолінійний), \% & $14,61 \pm 8,73$ & $16,33 \pm 8,67$ & $15,27 \pm 8,86$ \\
\hline Категорія D (нерухомі сперматозоїди), \% & $42,20 \pm 19,00$ & $38,26 \pm 17,61$ & $40,91 \pm 17,24$ \\
\hline Сперматозоїди з нормальною будовою, \% & $33,26 \pm 14,58$ & $36,63 \pm 13,76$ & $33,65 \pm 12,45$ \\
\hline Патологічні сперматозоїди, \% & $66,98 \pm 14,80$ & $63,34 \pm 13,77$ & $66,34 \pm 12,45$ \\
\hline
\end{tabular}

Примітка. 1. $\mathrm{n}$ - число спостережень

Таблиця 2

Аналіз даних спермограм пацієнтів із азооспермісю за 2010-2012 pp. (x \pm Sx)

\begin{tabular}{|c|c|c|c|}
\hline Показники & 3а 2010 p., $\mathrm{n}=58$ & 3а 2011 p., $\mathrm{n}=61$ & 3а 2012 p., $\mathrm{n}=69$ \\
\hline Вік, роки & $30,87 \pm 7,26$ & $30,57 \pm 6,23$ & $33,21 \pm 6,99$ \\
\hline Час розрідження, хв & $25,00 \pm 5,47$ & $25,71 \pm 9,71$ & $26,19 \pm 10,38$ \\
\hline В'язкість, см & $0,16 \pm 0,16$ & $0,14 \pm 0,13$ & $0,15 \pm 0,13$ \\
\hline Об'єм, мл & $2,27 \pm 1,40$ & $3,23 \pm 1,10$ & $2,71 \pm 1,33$ \\
\hline
\end{tabular}

Примітка. 1. $\mathrm{n}$ - число спостережень

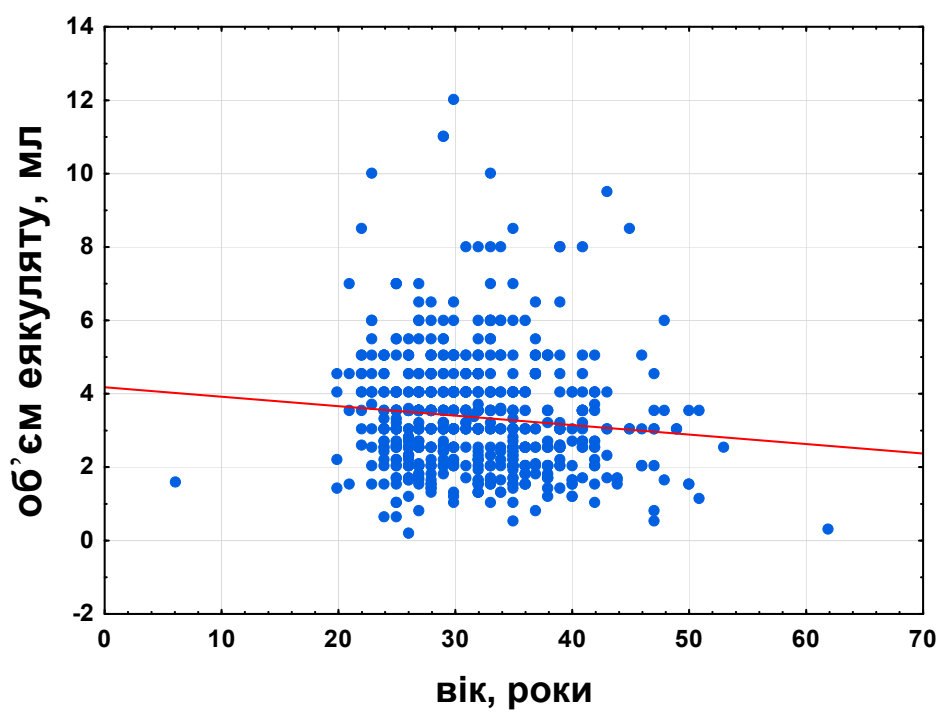

Рис. 1. Регресійний аналіз між віком та об’ємом еякуляту в пацієнтів досліджуваної групи у 2012 p. (n=679)

2012 р. демонструє тенденцію до негативної лінії тренда (рис. 1). За допомогою формули регресії (об'єм еякуляту, мл=4,1822-0,0258*x, де х - вік чоловіка, роки) можна в межах вірогідного інтервалу $(\mathrm{p}<0,05)$ розрахувати об'єм еякуляту.

Результати багатофакторного регресійного аналізу між кількістю сперматозоїдів в еякуляті, віком пацієнтів та відсотком патологічних сперматозоїдів у пацієнтів досліджуваної групи демонструють прогностичне прогресивне збільшення відсотка патологічних сперматозоїдів, пов'язане $з$ віком (рис. 2). 


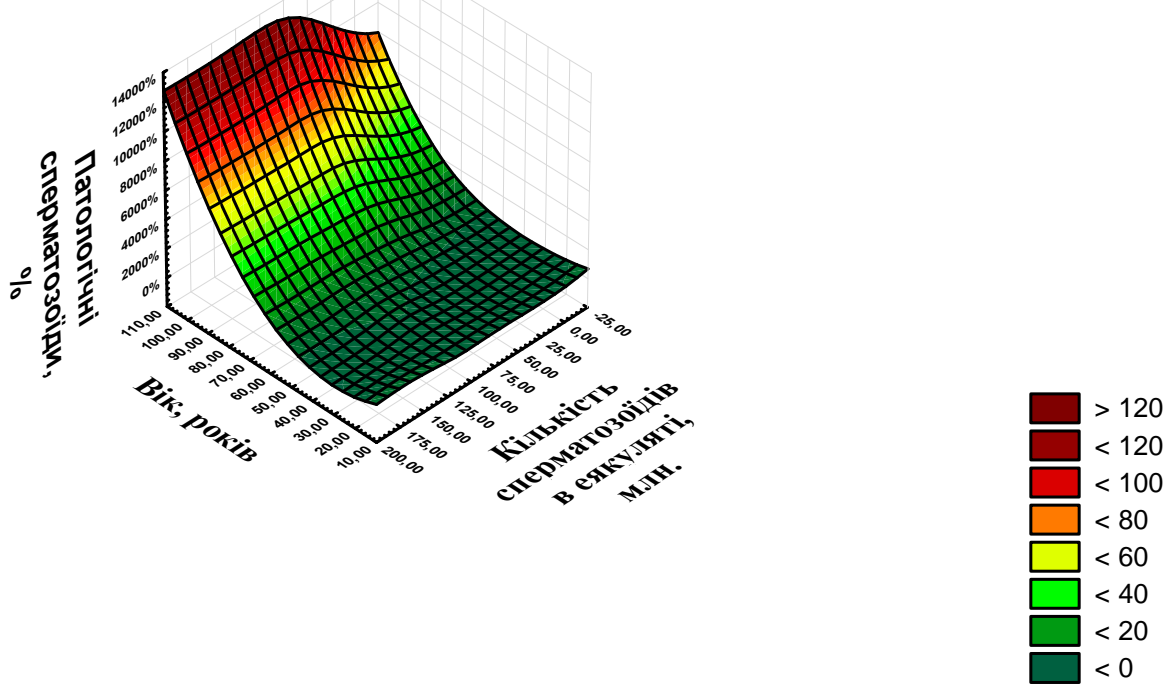

Рис. 2. Багатофакторний регресійний аналіз між кількістю сперматозоїдів в еякуляті, віком пацієнтів та відсотком патологічних сперматозоїдів у пацієнтів досліджуваної групи у 2012 p. (n=679)

\section{Висновки}

1. Астенозооспермію в досліджуваній групі зумовлено тенденцією до значного зниження відсотка рухомих сперматозоїдів категорії В (рух повільний прямолінійний).

2. Багатофакторний регресійний аналіз у пацієнтів досліджуваної групи демонструє прогностичне прогресивне збільшення відсотка патологічних сперматозоїдів, пов'язане з віком.

Перспективи подальших досліджень. Перспективним є подальше вивчення етіології, патогенезу, діагностики та лікування чоловічого безпліддя, що на даний час є пріоритетним напрямком сучасної андрології та репродуктології.

\section{Література}

1. Abdella A. M. Biochemical markers in semen and their correlation with fertility hormones and semen quality among Sudanese infertile patients / Abdelmula M. Abdella, Al-Fadhil E. Omer, Badruldeen H. Al-Aabed // Afr. J. Biochem. Res. - 2010. - Vol. 4, № 11. - P. 255-260.

2. Birenbaum-Carmeli D.Masculinity and Marginality: Palestinian Men's Struggles with Infertility in Israel and Lebanon / D. Birenbaum-Carmeli, M. C. Inhorn // J. of Middle East Women's Studies. - 2009. - Vol. 5, № 2. - P. 23-52.

3. Davar R. Semen parameters of non-infertile smoker and non-smoker men / R. Davar, L. Sekhavat, N. Naserzadeh // J. Med. Life. - 2012. - Vol. 5, № 4. - P. 465-468.

4. Semen analysis before and after antibiotic treatment of asymptomatic chlamydia- and ureaplasma-related pyospermia / B. Pajovic, N. Radojevic, M. Vukovic [et al.] // Andrologia. 2013. - Vol. 45, № 4. - P. 266-271.

5. Spermogram changes and pregnancy rate in Egyptian infertile males before and after varicocelectomy / H.A. ALBadawy, D.A. El Maleek Hassan Pessar, A.M. Kamel [et al.] // J. of Am. Science. - 2012. - Vol. 8, № 11. - P. 583-586.

\section{АНАЛИЗ РЕЗУЛЬТАТОВ СПЕРМОГРАММ МЕДИЦИНСКОГО ЦЕНТРА ЛЕЧЕНИЯ БЕСПЛОДИЯ}

\section{К.А. Владыченко, Л.Т. Савчук}

Резюме. Исследованы показатели спермограмм за 2010-2012 гг., выполненные в медицинском центре лечения бесплодия г. Черновцы. Оценка спермограмм выполнена согласно рекомендациям ВОЗ 2000г. Проведен статистический анализ результатов обследования 1935 мужчин, при котором установлено общую тенденцию к увеличению процента астенозооспермии за счет категории В.

Ключевые слова: мужское бесплодие, диагностика, спермограмма.

\section{SEMEN ANALYSES EVALUATION IN MEDICAL CENTRE FOR INFERTILITY TREATMENT}

\section{K.A. Vladychenko, L.T. Savchuk}

Abstract. Semen analyses, made in Chernivtsi Medical Centre for Infertility Treatment from 2010 to 2012 were studied. The parameters were evaluated as recommended by WHO, 2000. 1,935 men where involved in the study. A general tendency of increasing asthenozoospermia in B category was found.

Key words: male infertility, diagnostics, semen analysis.

Bukovinian State Medical University (Chernivtsi) ${ }^{1}$ Medical Centre for Infertility Treatment (Chernivtsi) 